\title{
PROJECT MANAGEMENT - SUPPORT FOR ATTRACTING EUROPEAN FUNDS AND CONDITION OF THE DEVELOPMENT OF THE ROMANIAN SOCIETY
}

\author{
Diana RANF \\ ranfd@yahoo.com \\ “NICOLAE BĂLCESCU”LAND FORCES ACADEMY, SIBIU, ROMANIA
}

\begin{abstract}
The article contains an analysis of the state of absorption of European funds in Romania with a focus on the Central Region. The article highlights the role of project management as a method of attracting European funds. The importance of good management of the European funds is of particular importance for the increase of the welfare at national level by implementing a series of changes really necessary and important for the progress of the community. The purpose of the analyzes performed regarding the access and absorption stage of the funds, regarding the problems encountered, is to serve as support in the planning of the following financing periods. The practice of efficient project management opens the door to new projects, whose immediate effect is the increase of the absorption of European funds, followed by a recovery of the Romanian economy and the increase of the prestige of our country among the member countries of the European Union. But, before discussing prestige, recognition, reputation, the emphasis must be placed on ensuring a viable economic growth, which is really reflected in the living conditions of the population.
\end{abstract}

\section{KEYWORDS:}

Economic development, European funds, management, project management

\section{Introduction}

The article addresses the topic of project management in the context in which the main concern of the Romanian economists, specialists and society in general should be the increase of the welfare in general, of the economy in particular. Thus, the focus should be on opportunities in general. One of the growth opportunities is still represented by the European funds.
The status of a member state of the European Union gives our country this opportunity. In the financial year 2007-2013, Romania received 19.2 billion Euros from the total amounts allocated by the EU for structural and cohesion funds. According to the population, these amounts represented less than EUR 1000 EUR / inhabitant, being (next to Bulgaria) the lowest level compared to the other countries of Central and Eastern Europe, which have benefited 
from EU allocations per inhabitant about twice as much (Zaman \& Georgescu, 2014).

According to statistics, by the end of 2013, Romania attracted about 7 billion Euros out of the total 19.2 billion Euros of EU allocations for 2007-2013, respectively an absorption rate of only $36.7 \%$, the lowest among the countries of Central and Eastern Europe compared to that date. Considering that in the Romanian economy, according to the data, approximately 16.6 billion Euro entered into structural and cohesion funds from 2007 and until November 2016, i.e. an absorption rate of $89 \%$, it can be concluded that there have been registered substantial improvements in the absorption rate for the same period in 2013-2016.

The analysis of these data is justified by the fact that European funds are Romania's chance to recover the socioeconomic development gaps and to become competitive at European level.

The performance recorded by Romania regarding the absorption of European funds in the period 2007-2013 has created positive effects in the Romanian economy. Compared to the same quarter of 2018, the gross domestic product increased by $4.4 \%$ in the second quarter of 2019. This growth is justified by the positive contributions of some branches of the economy, such as: wholesale and retail trade, hotels and restaurants $(+1.2 \%)$; constructions $(+0.5 \%)$; information and communications $(+0.5 \%)$; professional, scientific and technical activities; administrative services activities and support services activities $(+0.5 \%)$.

With all the economic growth recorded during this period, Romania faces a series of negative indicators, such as for example the budget deficit which was declared by 2.7 in October this year, due to the increase of some categories of expenses, such as those related to personnel compared to the year 2018.

This is the economic context in which it finds its justification to intensify the effort in the direction of accessing European funds, which can support the development needs of the Romanian economy and society in general.

\section{Literature review}

Project management, a relatively new but topical field, should not only be seen as an instrument for attracting funds to achieve cohesion objectives, but also as a way of institutional development, a new way of thinking and acting through which we can increase personal and organizational performance. Institutions should adopt project management to reach a certain level of organization that will allow them to achieve strategic goals to meet current demands for change and innovation (Ranf, 2014).

Even from the meanings attributed by different authors to the notion of project, we can conclude that it can be regarded as a working method that allows for continuous improvement at both individual and institutional levels. Thus, it can be regarded as a "temporary effort to produce a unique product, service or result" (Lewis, 2010, p. 5). Basically, the project is a mission with a known end point (Newton, 2007). The project is also considered as an intention (idea) which is essentially characterized by the uniqueness of the given conditions, for example: goal setting, time, financial, personnel and other limitations, different from other intentions and other projects (Baltador \& Hausmann, 2006).

According to some authors, the project is defined in a simple and general way, namely ,a capital investment for a certain period, in order to create productive assets". In a project, people's energy and inventiveness play a role as important as the use of material and financial resources, so that the term "capital" refers equally to human and material resources (Dumitrașcu \& Pascu, 2005).

3. Analysis of the absorbation of European funds - comparison by regions According to data published by the Ministry of European Funds, in September 2019, the amounts of money received by Romania from the European Commission amount to 9.74 billion Euros, out of the total of 25.2 billion Euros (the amount made available 
to Romania by the European Union for the period 2014-2020), the absorption rate thus reaching $32 \%$.

This money is used in infrastructure projects, such as the construction of highways and railways, support for small and mediumsized enterprises, adaptation to climate change, thermal rehabilitation of buildings, investments in human resources and many other objectives that aim to strengthen the economy and to increasing market competitiveness.

Compared with the previous period when, in 2013, at the end of the period, an absorption rate of $36.7 \%$ was recorded, with a sustained effort, at least as good results can be obtained in the current financial year.

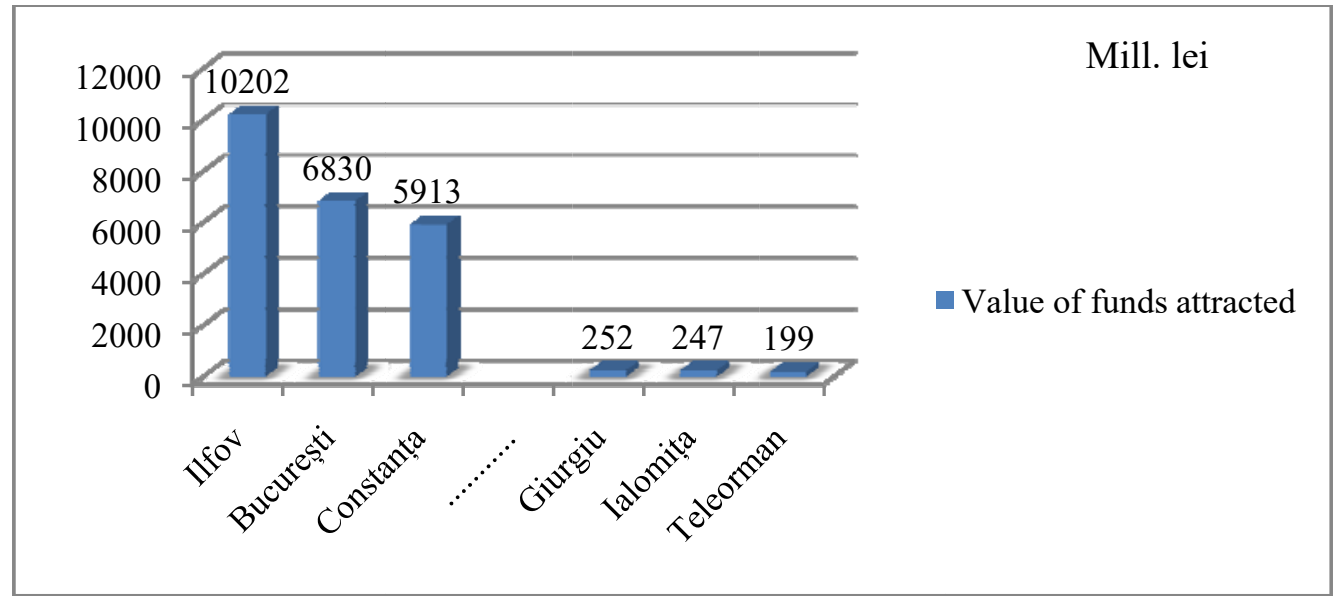

Figure no. 1. Comparison between regions that attracted the highest and lowest values of European funds in the period 2014-2019

(Source: adapted from Botea, 2019)

According to the data provided by the Ministry of European Funds, the areas that attracted the most European funds during 20142020: Ilfov, Bucharest and Constanţa. Even though Ilfov has carried out fewer contracts (48) for the accessed projects, the value of their European funding has exceeded 10 billion lei, while Bucharest has carried out 260 contracts with a total European funding of 6.83 billion lei, shows official data.

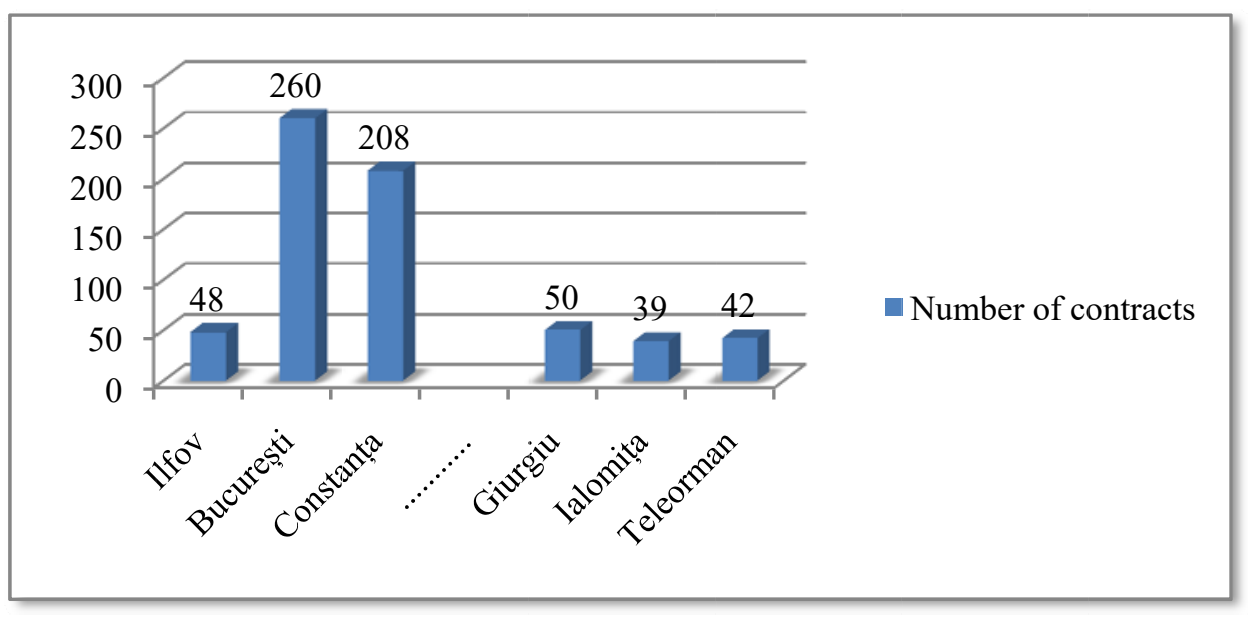

Figure no. 2. Comparison between the regions that attracted the highest and the lowest values of the European funds in the period 2014-2019 in terms of the contracts concluded

(Source: adapted from Botea, 2019) 
At the opposite pole is Teleorman county, with financing worth 199 million lei and 42 projects, followed by Ialomiţa counties, which contracted 39 projects with
European funding of 247 million lei, and Giurgiu with financing of 252 million lei and 50 contracts financed with European money.

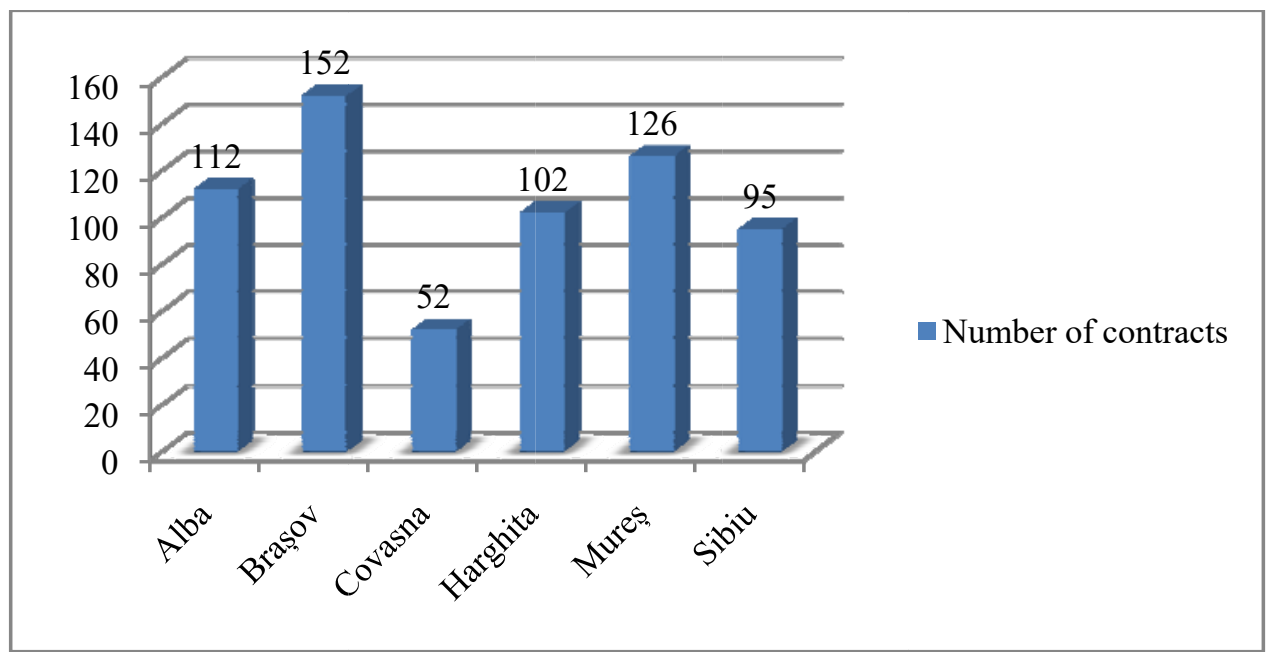

Figure no. 3. Comparison between the counties in the Central Region according to the contracts concluded for accessing European funds in the period 2014-2019

(Source: adapted from Botea, 2019)

Figure no. 3 analyzes the number of contracts concluded within the central development region, consisting of the counties of Sibiu, Braşov, Alba, Mureș, Covasna and Harghita. Comparing Figure no. 3 with Figure no. 4, it can be seen that the number of contracts concluded does not correspond to the highest amount accessed. Alba county holds the record regarding the amounts absorbed in the period 2014-2019, the value of the contracts being represented by 1497 million lei, being followed by Brașov county with a value of contracts concluded of 1112 million lei.

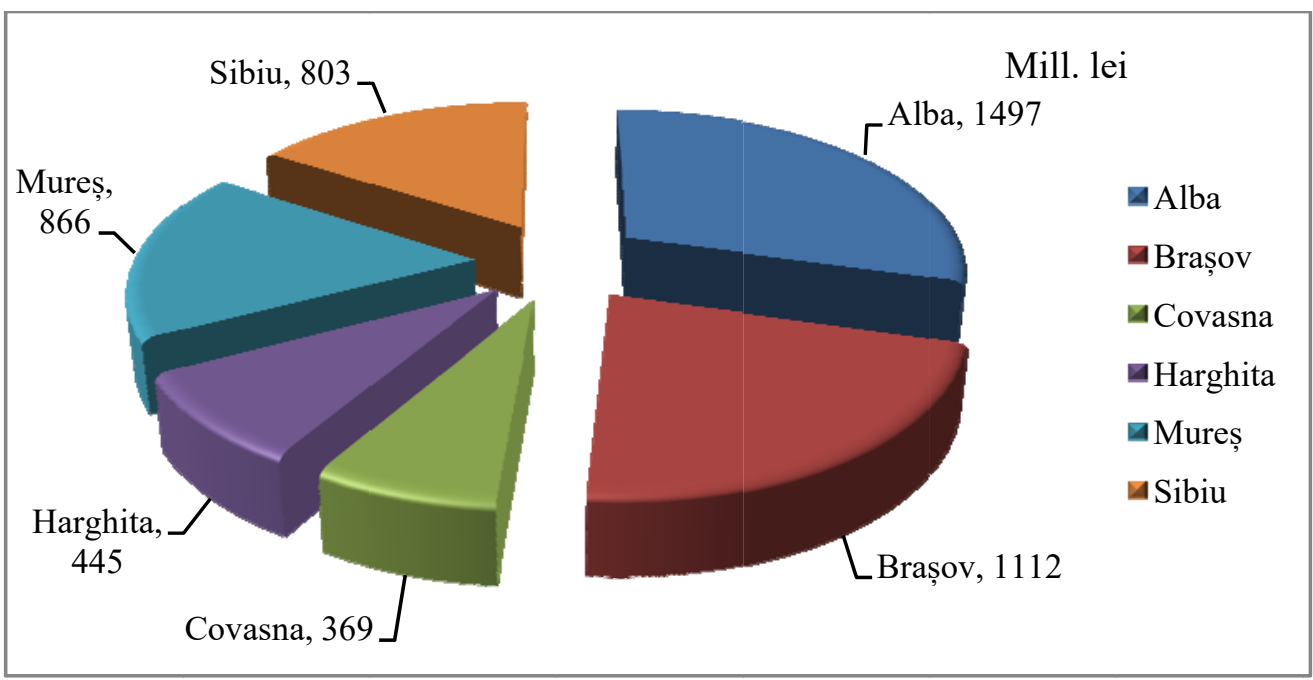

Figure no. 4. Comparison between the counties in the Central Region according to the contracts concluded for accessing European funds in the period 2014-2019

(Source: adapted from Botea, 2019) 
At the opposite pole is Covasna County, which attracted 369 million lei, concluding 52 contracts for accessing funds, followed by Harghita which attracted 445 million Euros.

The amounts that have been the object of the study are in the financial year 2014-2020, which will end at the end of 2020 and represent the signed contracts for which European funding has been approved.

\section{Conclusions}

These European funds can now make an important contribution to Romania's growth strategy. In this uncertain economic context, projects funded from European funds represent an important driver of economic growth. Thus the imperative of improving the rate of absorption of European funds appears, this aspect constituting as a first argument of the necessity of approaching the theme of project management in correlation with the phrase of European funds.

Comparing the evolution of the two financing periods 2007-2013, which finalized the absorption period (payments to beneficiaries) at the end of 2016, and the period 2014-2020, still in progress, we can deduce the following: the value of the European funds destined to Romania increased from 19.2 billion Euros (the value of European funding for 2007-2013) to 25.2 billion Euros (the value of European funding for 2014-2020), which shows a good negotiation of the budget. Another conclusion that comes from analyzing the evolution of access and payments to beneficiaries in the two periods, we can see a better start in the financial execution 2014-2020, which means increasing the level of experience in programming, spending and evaluating European money.

Improving the management processes of European projects by analyzing the problems that have affected their development so far offers a successful chance for future beneficiaries of European funds in the following funding periods, such as 2021-2027, but also makes important contributions to the scientific field of project management in general.

As solutions, consideration should be given to maintaining an awareness of the need to obtain qualifications and competences in the field of projects, on adopting project management as a form of leadership and promoting it as a micro and macroeconomic approach, professionalizing in the field, creating a true culture of projects at the level of regions, cities, public and private institutions.

\section{REFERENCES}

Baltador, L., Hausmann G., Schiffer, J., \& Baltador, M. (2006). Managementul proiectului. Sibiu: Editura Burg.

Botea, R. (2019). Topul zonelor care au atras cele mai multe fonduri europene în perioada 2014-2020: Ilfov, Bucureşti şi Constanţa au atras cele mai multe fonduri „,gratis “ de la UE, available at: https://www.zf.ro/eveniment/topul-zonelor-care-au-atras-cele-maimulte-fonduri-europene-in-perioada-2014-2020-ilfov-bucuresti-si-constanta-au-atras-celemai-multe-fonduri-gratis-de-la-ue-18222783, accessed on 15 November 2019.

Dumitrașcu, D., \& Pascu, V. R. (2005). Managementul proiectelor. Sibiu: Editura Universității "Lucian Blaga".

Lewis, P. J. (2010). Project Planning, Scheduling and Control. SUA: McGraw Hill Publishing House.

Newton, R. (2007). Managementul proiectelor. Bucureşti: Editura Meteor Press.

Ranf, D. E. (2014). Managementul proiectelor cu finanţare europeană - studiu teoretic şi practice. Vol. I, Sibiu: Editura Universităţii "Lucian Blaga" din Sibiu.

Zaman, G., \& Georgescu, G. (2014). Structural and Cohesion Funds Absorption in Romania. Balance of the 2007-2013 Financial Exercise and Lessons for the Current Period. Romanian Journal of Economics, Institute of National Economy, Vol. 38, Issue 1, 49-88. 